\title{
Epidemiology of neuropathic pain
}

\author{
Epidemiologia da dor neuropática
}

Irimar de Paula Posso ${ }^{1}$, Cláudia Carneiro de Araújo Palmeira², Érica Brandão de Moraes Vieira ${ }^{3}$

\section{ABSTRACT}

BACKGROUND AND OBJECTIVES: The prevalence of neuropathic pain varies according to specific situations, due to multiple etiologies and manifestations, and may be located anywhere in the nervous system, being classified as peripheral or central. The classification has been modified with a certain frequency by the International Association for the Study of Pain in recent years, and may, for example, be classified as possible, probable or permanent. This brief review analyzes aspects of neuropathic pain epidemiology in general Brazilian population and in different clinical situations.

CONTENTS: Data on neuropathic pain prevalence in general population are not reliable due to broad heterogeneity of studies, different definitions and evaluation methods. The same difficulties are found when neuropathic pain prevalence is evaluated in Brazil. The prevalence and/or incidence in different clinical situation varies according to specific clinical situation, since it has multiple etiologies and may be located anywhere in the nervous system. Clinical situations in which neuropathic pain is more frequent are herpes-zoster, diabetes, leprosy, trigeminal and glossopharyngeal neuralgia, low back pain, and also central neurological diseases.

CONCLUSION: Data on the incidence and/or prevalence of chronic pain with neuropathic characteristics are very different and although this type of pain is being broadly studied in recent years, epidemiological studies are relatively scarce and the methodology used varies a lot.

Keywords: Chronic pain, Epidemiology, Incidence, Neuropathic pain.

\section{RESUMO}

JUSTIFICATIVA E OBJETIVOS: A prevalência da dor neuropática é variada de acordo com a situação específica, devido às múltiplas etiologias e modos de manifestar-se, podendo localizar-se em qualquer nível do sistema nervoso, sendo classificada como periférica ou central. A classificação tem sido modificada com alguma frequência pela International Association for the Study of Pain nos últimos anos, podendo, por exemplo, ser classificada em possível, provável e definitiva. Nesta breve revisão, são analisados aspectos da epidemiologia da dor neuropática na populaçáo em geral, no Brasil e em diversas situaçôes clínicas.

CONTEÚDO: Os dados sobre a prevalência de dor com característica neuropática na população em geral não são fidedignos devido a grande heterogeneidade dos estudos, as diferentes definiçôes e aos métodos de avaliação utilizados. As mesmas dificuldades são encontradas quando se analisa a prevalência de dor com característica neuropática no Brasil. A prevalência el ou incidência nas diversas situaçôes clínicas varia de acordo com a situação clinica específica, uma vez que tem múltiplas etiologias e pode localizar-se em qualquer nível do sistema nervoso. As situaçôes clínicas em que a dor

1. Faculdade de Medicina do ABC, Departamento de Anestesiologia. São Paulo, SP, Brasil. 2. Universidade de Sáo Paulo, Faculdade de Medicina, Hospital das Clínicas, Controle de Dor do Instituto Central, Såo Paulo, SP, Brasil.

3. Universidade Federal do Maranháo, Hospital de Urgência e Emergência Dr. Clementino Moura, Departamento de Enfermagem, Ambulatório de Dor Crônica, Sáo Paulo, SP, Brasil.

Conflict of interests: none - Sponsoring sources: none.

\section{Correspondence to:}

Irimar de Paula Posso

Rua Iperoig, $749 / 111$

05016-000 São Paulo, SP, Brasil.

E-mail: irimar.posso@dor.org.br

(C) Sociedade Brasileira para o Estudo da Dor neuropática é mais frequente são o herpes-zoster, a diabetes, a hanseníase, o câncer, a infecção por vírus da imunodeficiência humana, síndrome do túnel do carpo, a neuralgia do trigêmeo e do glossofaríngeo, a lombalgia, e também as doenças neurológicas centrais.

CONCLUSĂO: Os dados de incidência e/ou prevalência da dor crônica com característica neuropática são muito diversos, apesar desse tipo de dor ser bastante estudado atualmente, os estudos epidemiológicos são relativamente escassos e a metodologia usada é muito variada.

Descritores: Dor crônica, Dor neuropática, Epidemiologia, Incidência,.

\section{INTRODUCTION}

Due to numerous chronic painful conditions classified as neuropathic pain (NP), prevalence varies according to specific situations, since NP has multiple etiologies and presentations, may be located in any nervous system level, being classified as peripheral NP when primary injury or disorder is located in the peripheral nervous system and as central NP when it is located in the central nervous system (CNS) and has numerous causes.

NP classification varies according to adopted criteria and has been modified with some frequency by the International Association for the Study of Pain (IASP) in recent years. It may, for example, be classified as possible, probable or permanent. In addition, progress in the understanding of chronic pain with neuropathic characteristics has been made difficult by the lack of epidemiologic investigation in the general population ${ }^{1}$.

Epidemiologic NP studies should be analyzed with regard to the incidence, which means the appearance of new cases in a certain period of time, while prevalence measures the number of current cases in a population in a certain period, between specific dates or during the whole life. Exact NP prevalence in the world population is unknown and in Brazil there are no accurate data on the prevalence of this pain among Brazilians ${ }^{2}$.

Epidemiology is a major clinical tool for the evaluation of NP management and prevention strategies, however there is no accurate information available because in a sense, NP describes a symptom or mechanism rather than a specific disease $e^{3}$.

A factor interfering with the study of NP prevalence is the method used for its diagnosis. There are currently several criteria and most commonly used tools are NP questionnaires (DN4) and especially the Leeds Assessment of Neuropathic Symptoms and Signs Score (S-LANSS) which aim at identifying predominantly neuropathic pain as different from nociceptive pain with no need for clinical exams. S-LANSS questionnaire was recently validated for the use in studies by mail, making the identification of pain of predominantly neuropathic origin easier and possible. Another tool is the painDETECT questionnaire, reliable screening tool, with high sensitivity, specificity and positive predictive accuracy, and may determine the prevalence of NP components in low back pain patients ${ }^{4,5}$.

A review article states that although NP may be acute in nature, in most patients it is chronic, originated from a large number of diseases, each one with different diagnostic definitions, which impairs the accurate estimate of NP prevalence and incidence, and although available epidemiologic literature is limited, estimated prevalence is $1.5 \%{ }^{6}$.

In addition, it is known that chronic NP is more prevalent among females, in older ages, in people with low education levels and with more labor absenteeism due to disease. Since the increase in life expectation has led to the appearance of chronic, benign or malignant diseases, it is expected a worldwide growth of the incidence of secondary NP among patients surviving treatments (oncologic or not). It is also known that NP is in general more severe and tends to chronicity, inducing further search for health care, especially primary health care, as compared to other types of chronic pain ${ }^{7-10}$. 


\section{PREVALENCE OF PAIN WITH NEUROPATHIC CHARACTERISTIC IN THE GENERAL POPULATION}

The lack of accurate prevalence and incidence data is due to broad heterogeneity of NP studies, to different definitions and evaluation methods used, however it is estimated between 1 and $6.9 \%$ and $10 \%$, but some studies admit that the neuropathic component may be present in $35 \%$ of all painful syndromes ${ }^{11}$.

Estimates of prevalence based on specific NP causes tend to be lower (1$2 \%)$ than those based on classic symptoms reports $(6-8 \%)^{3}$.

A systematic review of epidemiologic studies of NP in the general population, based on electronic data from January 1966 to December 2012, has shown that the incidence and prevalence of chronic pain with neuropathic characteristics vary between 3 and $17 \%$.

The best estimate of prevalence of pain with neuropathic characteristic probably varies between 6.9 and $10 \%$. These differences highlight the difficulties since there is no standardized evaluation for the identification of NP in epidemiologic studies ${ }^{11}$.

The first population-based study was carried out in the United Kingdom with the S-LANSS questionnaire and has found a prevalence of pain with neuropathic characteristic of $8 \%{ }^{1}$.

The first population-based study with the DN4 questionnaire carried out in France in 2008, with the version of the DN4 questionnaire using just the first seven items of the questionnaire has estimated the prevalence of pain with neuropathic characteristic in $7 \%{ }^{12}$.

An estimate of the prevalence and distribution of pain of predominantly neuropathic origin in the general population of three cities of the United Kingdom, involving 6 thousand people, by means of a previously validated and reliable data collection tools sent by mail, has identified the prevalence of chronic pain of $48 \%$ and the prevalence of pain of predominantly neuropathic origin of $8 \%{ }^{1}$.

Study with German population, where people were interviewed by telephone, has shown that in general $6.5 \%$ of respondents have reported pain with chronic neuropathic pain characteristics, and have reported higher intensity and more interference of pain in their daily activities as compared to individuals with chronic non-neuropathic pain ${ }^{13}$.

A study calculating NP pain incidence rates in the general population of The Netherlands has included 362,693 people registered during at least one year in the Integrated Basic Attention Information database between 1996 and 2003 and has identified 9135 new cases of NP, that is, 8.2 per 1000 patients/ year. Mononeuropathy and carpal tunnel syndrome were the most frequent types with 4.3 and 2.3 cases per 1000 patients/year, followed by diabetic peripheral neuropathy and postherpetic neuralgia with 0.72 and 0.42 per 1000 patients/year. NP was more common among females as compared to males and has reached its peak between 70 and 79 years of age ${ }^{14}$.

A study by mail using the DN4 questionnaire to evaluate the prevalence of chronic pain with or without neuropathic characteristic in the general French population has shown prevalence of $6.9 \%$ with confidence interval of $95 \%$ and the highest prevalence of chronic pain with neuropathic characteristic was associated to middle-age, manual professions and living in rural areas ${ }^{12}$. The epidemiologic analysis by the computerized system of general clinical records of United Kingdom from January 1992 to April 2002 has shown incidence of 40 per 100 thousand people/year for postherpetic neuralgia, 26 to 27 for trigeminal neuralgia, 1 to 2 for phantom limb pain and 15 to 16 for painful diabetic neuropathy, with decreasing rates along time for phantom limb pain and postherpetic neuralgia and increasing rates for painful diabetic neuropathy ${ }^{15}$.

A telephone survey based on a random sample of urban and rural families of a Canadian province using the DN4 questionnaire has identified chronic pain with NP symptoms in $17.9 \%$ of respondents, being predominant among females and those economically disadvantaged ${ }^{16}$.

A study carried out in 2008 has shown that the prevalence of NP in Austria was $3.3 \%$, being higher in patients with 41-50 (26\%) and 51-60 (25\%) years of age ${ }^{17}$.

\section{PREVALENCE OF PAIN WITH NEUROPATHIC CHARACTERISTIC IN BRAZIL}

In Brazil, chronic pain is a very frequent clinical condition, affecting between 28 and $41 \%$ of the Brazilian population ${ }^{18,19}$.
A study including 1597 people using the DN4 questionnaire has shown that the prevalence of chronic pain was $42 \%$, and $10 \%$ had chronic pain with neuropathic characteristic ${ }^{20}$, which is higher than United Kingdom $(8 \%)^{1}$ and France $(6.9 \%)^{12}$ rates. In the Brazilian study DN4 items which are part of the clinical evaluation were used, which was not the case in other population-based studies.

\section{NEUROPATHIC PAIN IN DIFFERENT CLINICAL SITUATIONS}

The prevalence and/or incidence of NP will be analyzed in different clinical situations, because it varies according to specific clinical condition, since it has multiple etiologies and may be located anywhere in the nervous system.

\section{Herpes-Zoster}

It is estimated that in the United States 1 to 3 million people suffer of postherpetic neuralgia and that in Europe approximately 6 to 7.7 million people have NP sometime in life ${ }^{21}$.

The prevalence of post-herpetic NP varies between 8 and 19\% with pain one month after erythema, or $8 \%$ with pain three months after its onset ${ }^{22}$. Postherpetic neuralgia is more frequent among elderly people ${ }^{23}$. The intensity of pain with neuropathic characteristic is reported as severe by 2 to $10 \%$ of patients ${ }^{24}$.

A systematic review of NP epidemiologic studies in the general population, based on electronic data from January 1066 to December 2012, has shown that incidence and prevalence rates of chronic pain with neuropathic characteristic, such as postherpetic neuralgia, has varied between 3.9 and 42.0/100 thousand people/year ${ }^{11}$.

A study using medical data from $51,448,491$ patients of the health insurance service of Korea between 2009 and 2013 has shown incidence of postherpetic neuralgia of 2.5 per 1000 people/year, strongly related to age and gender, and it seems to be considerably higher as compared to Western populations, however for gender and age, predisposition was similar ${ }^{25}$.

\section{Diabetes}

Literature estimates that diabetic neuropathy affects between 16 and $26 \%$ of patients, however according to a different study, the prevalence in the general population varies from 10 to $20 \%^{26-28}$.

In the United Kingdom, the prevalence of diabetic neuropathy was 26.4 among diabetes type 2 patients ${ }^{29}$. A Spanish study evaluating 1011 people with diabetes for more than 10 years has shown that $39.6 \%$ met NP criteria, being that $63.2 \%$ of them had already clinical manifestations ${ }^{30}$. The prevalence of neuropathy was even higher in Saudi Arabia $(65.3 \%)^{31}$.

A cross-sectional study using a structured questionnaire and exam, which has evaluated a sample of 350 diabetic patients, has shown an estimated prevalence of chronic painful peripheral neuropathy of $16.2 \%$ among diabetic people, as compared to $4.9 \%$ of the control sample $(\mathrm{p}<0.0001)^{32}$.

Chronic painful diabetic symmetric distal sensory-motor polyneuropathy is present in $13-26 \%$ of diabetic patients. Between 25 and $62 \%$ of patients with idiopathic peripheral neuropathy have pre-diabetes and $13-26 \%$ have NP. The highest frequency is found among patients with clinical presentation of diabetes mellitus (DM) followed by individuals with intolerance to glucose, fasting glucose and finally in those with normoglycemia ${ }^{33}$.

A study analyzing the prevalence has estimated that 20 to $24 \%$ of USA patients had painful diabetic neuropathy although data on risk factors for painful diabetic neuropathy are limited; however NP duration and poor glycemic control are important factors and between 25 to $50 \%$ of adults above 50 years of age develop postherpetic neuralgia, depending on the use of early antiviral therapy for herpes-zoster. Increased age, higher pain intensity, skin eruption severity, higher degree of sensory deficiency and psychic distress are risk factors for postherpetic neuralgia ${ }^{22}$.

\section{Leprosy}

$\mathrm{NP}$ is recognized as late leprosy complication.

A cross-sectional study with leprosy patients treated for at least five years in a rural area of Ethiopia has shown that $70.3 \%$ have reported symptoms suggestive of $\mathrm{NP}^{34}$.

A study carried out in India has shown that $21 \%$ of leprosy patients also 
had NP, being that $95.5 \%$ had sensory impairment and 50\% motor impairment. NP was associated to nervous enlargement and painful skin spots ${ }^{35}$. A study evaluating pain in Ethiopian recently treated leprosy patients, using the General Health Questionnaire (GHQ-12), the Brief Pain Inventory (BPI) questionnaire and DN4 and LANSS questionnaires has shown that pain of any type was experienced by $60 \%$ of patients, pure nociceptive pain by $43 \%$, pure NP by $11 \%$ and mixed pain by $6 \%{ }^{36}$.

Considering the proportion of postoperative chronic pain as compared to total surgeries, the incidence was estimated in 1.8 to $6.7 \%$ in the United States, and in 0.5 to $14 \%$ in Great Britain. With regard to the development of chronic pain after ambulatory surgeries, prevalence may be high varying between 10 and $50 \%^{37,38}$.

A study evaluating the incidence of postoperative chronic pain has shown that the incidence of NP was $31.9 \%$ six months after surgery and has increased to $40.3 \% 12$ months after surgery ${ }^{39}$.

With regard to type of pain, complex regional pain syndrome (CRPS) is present in approximately 3 to $25 \%$ of patients, and NP in 0.5 to $1.5 \%$ of patients, depending on the surgical procedure ${ }^{37,38}$. In distal radium fracture, the incidence of CRPS I may be 1 to $32.2 \%$ of patients $\mathrm{s}^{40,41}$.

Another study has shown incidence of CRPS of 5.46 per 100 thousand people/year and prevalence by period of 20.57 by 100 thousand people/year ${ }^{42}$. The probability of CRPS is higher in patients submitted to surgeries with significant nerve and tissue injury, such as amputations, thoracotomies, breast surgeries and limbs surgeries. In amputated patients, the incidence of CRPS may reach $85 \%{ }^{37,38}$.

\section{Cancer}

Neuropathic cancer pain may be caused by mononeuropathies and polyneuropathies, plexopathies, medullary compression, complex regional pain syndrome and deafferentation, and may result from direct tumor action or be induced by treatment ${ }^{2}$.

More than $50 \%$ of hospitalized cancer patients report pain, being that $81 \%$ of them report pain in two or more sites, which may be nociceptive, neuropathic or mixed. It is estimated that $36 \%$ of cancer patients suffer pain with neuropathic component, however a study has shown that $47.5 \%$ of patients had pain with neuropathic component, of which $7.7 \%$ had pure NP and $39.8 \%$ mixed pain ${ }^{43-45}$.

A systematic review including 14 studies with confirmation tests to confirm $\mathrm{NP}$ in cancer patients has shown that the prevalence of NP with confidence interval of $95 \%$ was $19 \%(9.4 \%-28.4 \%)$ for a conservative estimate and of $39.1 \%(15.3 \%-22.1 \%)$ for a liberal estimate including patients with mixed pain. The prevalence of NP with a mechanism has varied from a conservative estimate of $18.7 \%(15,3 \%-22,1 \%)$ to a liberal estimate of $21.4 \%$ (15.2\%-27.6\%) of all recorded cancer pains ${ }^{46}$.

A review involving 29 studies on NP and cancer, published until 2014 has shown global prevalence of $31.2 \%$, with slightly higher prevalence in palliative or hospitalized patients as compared to ambulatory patients ${ }^{47}$.

\section{Infection by human immunodeficiency virus}

Neurologic manifestations are frequent in human immunodeficiency virus infections (HIV), being the first disease manifestation in $10 \%$ of cases and $30-50 \%$ of patients will report neurological symptoms in some stage of the disease. Peripheral neuropathies are commonly associated to HIV infections and distal peripheral neuropathy is the most frequent form, being symptomatic in $35 \%$ of patients ${ }^{48,49}$.

\section{Carpal tunnel syndrome}

The prevalence of carpal tunnel syndrome varies from 51 to $125: 100,000$ being more frequent among females between 40 and 60 years of age $\mathrm{e}^{50,51}$. However, a study aiming at evaluating clinical NP characteristics in carpal tunnel syndrome patients using painDETECT as questionnaire to distinguish NP has not shown significant differences among patients with and without NP; however pain intensity and night pain were higher for those with $\mathrm{NP}^{52}$.

\section{Trigeminal neuralgia}

Annual trigeminal neuralgia (TN) prevalence is 4.3 people per 100 thousand inhabitants, affecting more females than males $(5.7 \% \times 2.5 \%$ per 100 thousand inhabitants) and older people (11 cases for every 100 thousand people above 75 years of age). When NP is symptomatic, multiple sclerosis is the most common etiology, in general affecting younger patients as compared to classic neuralgias ${ }^{2}$.

\section{Glossopharyngeal neuralgia}

A systematic review of NP epidemiologic studies in the general population, based on electronic data from January 1966 to December 2012, has shown that incidence and prevalence of chronic glossopharyngeal pain with neuropathic characteristic has varied between 0.2 and $0.4 / 100$ thousand people/year ${ }^{11}$.

\section{Low back pain}

According to painDETECT questionnaire, the prevalence in the general population was that $14.5 \%$ of German females, and $11.4 \%$ of German males had low back pain with predominant NP component $t^{5}$.

A study investigating the prevalence of pain and its distribution characteristics in patients with chronic lumbar problems has shown prevalence of $\mathrm{NP}$ in $31.9 \%$ of patients ${ }^{53}$.

\section{Central neuropathic pain}

There is central NP in diseases of acute or chronic evolution and it may be present in cases of central injury in any level, however, the highest prevalence is in spinal cord and bulb and ventrolateral nuclei of the thalamus. Major cause of medullar NP are traumas (60-70\%), but it may be caused by surgeries, inflammatory processes, neoplasias, vascular diseases and myelopathy, while encephalic central pains are present in $90 \%$ of cases and have vascular causes, but may also be caused by infections or tumors ${ }^{2}$. Patients with traumatic medullary injuries develop NP in up to $70 \%$ of cases and pain is in general absent in the initial phase, appearing days or weeks after, and in $70 \%$ of these patients, pain persists after one year ${ }^{54,55}$. Central pain is developed in $44 \%$ of patients with brain stem infarcts and in syringomyelia this pain is prevalent in $75 \%$ of patients ${ }^{56,57}$.

In multiple sclerosis, central pain is prevalent in $28 \%$ of patients, however a study using the PainDETECT questionnaire to evaluate 377 ambulatory patients with early multiple sclerosis has evidenced NP in $4.2 \%$ of patients $s^{2,58}$.

\section{CONCLUSION}

Data on the incidence and/or prevalence of chronic pain with neuropathic characteristic are very heterogeneous and although this pain is being frequently studied, epidemiologic studies are relatively scarce and the methodology varies, in addition to the fact that there are numerous chronic painful conditions classified as NP, which have multiple etiologies and different presentations, since injury or disease may affect any level of the nervous system.

\section{REFERENCES}

1. Torrance N, Smith BH, Bennett MI, Lee AJ. The epidemiology of chronic pain of predominantly neuropathic origin. Results from a general population survey. J Pain. 2006;7(4):281-9

2. Macedo DDP. Epidemiologia. In: Drummond JP, Marquez JO. Dor neuropática. São Paulo: Âmbito Editores; 2007. 18-29p.

3. Smith BH, Torrance N. Epidemiology of neuropathic pain and its impact on quality of life. Curr Pain Hedache Rep. 2012;16(3):191-8.

4. Bennett MI, Smith BH, Torrance N, Potter J. The S-LANSS score for identifying pain of predominantly neuropathic origin: validation for use in clinical and postal research. J Pain. 2005;6(3):149-58.

5. Freynhagen R, Baron R, Gockel U Tölle TR. painDETECT: a new screening questionnaire to identify neuropathic components in patients with back pain. Curr Med Res Opin. 2006;22(10):1911-20.

6. Taylor RS. Epidemiology of refractory neuropathic pain. Pain Pract. 2006;6(1):22-6.

7. Vadalouca A, Siafaka I, Argyra E, Vrachnou E, Moka E. Therapeutic management of chronic neuropathic pain: an examination of pharmacologic treatment. Ann N Y Acad Sci. 2006;1088:164-86.

8. Benitez-Rosario MA, Salinas-Martin A, Martinez-Castillo LP, Martin-Ortega JJ, Feria M. Intermittent nasogastric drainage under sedation for unresponsive vomiting in terminal bowel obstruction. J Pain Symptom Manage. 2003;25(1):4-5.

9. Dworkin RH. An overview of neuropathic pain: syndromes, symptoms, signs, and several mechanisms. Clin J Pain. 2002;18(6):343-9.

10. Cavenagh J, Good P, Ravenscroft P. Neuropathic pain: are we out of the woods yet? Intern Med J. 2006;36(4):251-5.

11. van Hecke O, Austin SK, Khan RA, Smith BH, Torrance N. Neuropathic pain in the genera lpopulation: a systematic review of epidemiological studies. Pain. 2014;155(4):654-62.

12. Bouhassira D, Lantéri-Minet M, Attal N, Laurent B, Touboul C. Prevalence of chronic pain with neuropathic characteristics in the general population. Pain. 2008;136(3):380-7.

13. Ohayon MM, Stingl JC. Prevalence and comorbidity of chronic pain in the German general population. J Psychiatr Res. 2012;46(4):444-50.

14. Dieleman JP, Kerklaan J, Huygen FJ, Bouma PA, Sturkenboom MC. Incidence rates and treatment of neuropathic pain conditions in the general population. Pain. 2008;137(3):681-8.

15. Hall GC, Carroll D, Parry D, McQuay HJ. Epidemiology and treatment of neuropathic pain: the 
UK primary care perspective. Pain. 2006;122(1-2):156-62.

16. Toth C, Lander J, Wiebe S. The prevalence and impact of chronic pain with neuropathic pain symptoms in the general population. Pain Med. 2009;10(5):918-29.

17. Gustorff B, Dorner T, Likar R, Grisold W, Lawrence K, Schwarz F, Rieder A. Prevalence of self-reported neuropathic pain and impact on quality of life: a prospective representative survey. Acta Anaesthesiol Scand. 2008;52(1):132-6.

18. Dias T, Latorre MR, Appolinario J, Ferreira KA, Teixeira MJ. The prevalence of chronic pain in Sao Paulo (Brazil): a population-based study using telephone interview, in: $5^{\text {th }}$ World Pain Congress World Institute of Pain - WIP. New York: Wiley-Blackwell, 2009.

19. Sá K, Baptista AF, Matos MA, Lessa I. [Prevalence of chronic pain and associated factors in the population of Salvador, Bahia]. Rev Saude Publica. 2009;43(4):622-30. Portuguese.

20. De Moraes Vieira EB, Garcia JB, da Silva AA, Mualem Araújo RL, Jansen RC. Prevalence, characteristics, and factors associated with chronic pain with and without neuropathic characteristics in Sáo Luís, Brazil. J Pain Symptom Manage. 2012;44(2):239-51.

21. Bowsher D. Neurogenic pain syndromes and their management. Br Med Bull. 1991;47(3):644-66.

22. Schmader KE. Epidemiology and impact on quality of life of postherpetic neuralgia and painful diabetic neuropathy. Clin J Pain. 2002;18(6):350-4.

23. Cluff RS, Rowbotham MC. Pain caused by herpes zoster infection. Neurol Clin. 1998;16(4):813-32.

24. Jung BF, Johnson RW, Griffin DR, Dworkin RH. Risk factors for postherpetic neuralgia in patients with herpes zoster. Neurology. 2004;62(9):1545-51.

25. Hong MJ, Kim YD, Cheong YK, Park SJ, Choi SW, Hong HJ. Epidemiology of postherpetic neuralgia in Korea: an electronic population health insurance system based study. Medicine (Baltimore). 2016;95(14):e3304

26. Jensen TS, Backonja MM, Hernández Jiménez S, Tesfaye S, Valensi P, Ziegler D. New perspectives on the management of diabetic peripheral neuropathic pain. Diab Vasc Dis Res. 2006;3(2):108-19.

27. Al-Daghri NM, Al-Attas OS, Al-Rubeaan K, Sallam R. Adipocytokine profile of type 2 diabetics in metabolic syndrome as defined by various criteria. Diabet Metabol Res Rev. 2008;24(1):52-8.

28. Lu B, Yang Z, Wang M, Yang Z, Gong W, Yang Y, et al. High prevalence of diabetic neuropathy in population-based patients diagnosed with type 2 diabetes in the Shanghai downtown. Diabetes Res Clin Pract, 2010;88(3):289-94.

29. Davies M, Brophy S, Williams R, Taylor A. The prevalence, severity, and impact of painful diabetic peripheral neuropathy in type 2 diabetes. Diabetes Care. 2006;29(7):1518-22.

30. Miralles-García JM, de Pablos-Velasco P, Cabrerizo L, Pérez M, López-Gómez V. Prevalence of distal diabetic polyneuropathy using quantitative sensory methods in a population with diabetes of more than 10 years' disease duration. Endocrinol Nutr. 2010;57(9):414-20.

31. Halawa MR, Karawagh A, Zeidan A, Mahmoud AE, Sakr M, Hegazy A. Prevalence of painful diabetic peripheral neuropathy among patients suffering from diabetes mellitus in Saudi Arabia. Curr Med Res Opin. 2010;26(2):337-43

32. Daousi C, MacFarlane IA, Woodward A, Nurmikko TJ, Brundred PE, Benbow SJ. Chronic painful peripheral neuropathy in an urban community: a controlled comparison of people with and without diabetes. Diabet Med. 2004;21(9):976-82.

33. Ziegler D, Papanas N, Vinik AI, Shaw JE. Epidemiology of polyneuropathy in diabetes and prediabetes. Handb Clin Neurol. 2014;126:3-22.

34. Ramos JM, Alonso-Castañeda B, Eshetu D, Lemma D, Reyes F, Belinchón I, et al. Prevalence and characteristics of neuropathic pain in leprosy patients treated years ago. Pathog Glob Health. 2014;108(4):186-90.

35. Lasry-Levy E, Hietaharju A, Pai V, Ganapati R, Rice AS, Haanpää M, et al. Neuropathic pain and psychological morbidity in patients with treated leprosy: a cross-sectional prevalence study in Mumbai. PLoS Negl Trop Dis. 2011;5(3):e981.

36. Haroun OM, Hietaharju A, Bizuneh E, Tesfaye F, Brandsma JW, Haanpää M, Rice AS, Lockwood
DN. Investigation of neuropathic pain in treated leprosy patients in Ethiopia: a cross-sectional study. Pain. 2012;153(8): 1620-4

37. Visser EJ. Chronic post-surgical pain: epidemiology and clinical implications for acute pain management. Acute Pain. 2006;8(2):73-81.

38. Akkaya T, Ozkan D. Chronic post-surgical pain. Agri. 2009;21(1):1-9.

39. Sansone P, Pace MC, Passavanti MB, Pota V, Colella U, Aurilio C. Epidemiology and incidence of acute and chronic post-surgical pain. Ann Ital Chir. 2015;86(4):285-92.

40. Jellad A, Salah S, Ben Salah Frih Z. Complex regional pain syndrome type I: incidence and risk factors in patients with fracture of the distal radius. Arch Phys Med Rehabil. 2014;95(3):487-92.

41. Dijkstra PU, Groothoff JW, ten Duis HJ, Geertzen JH. Incidence of complex regional pain syndrome type I after fractures of the distal radius. Eur J Pain. 2003;7(5):457-62.

42. Sandroni P, Benrud-Larson LM, McClelland RL, Low PA. Complex regional pain syndrome type I: incidence and prevalence in Olmsted country, a population-based study. Pain. 2003;103(1-2):199-207.

43. Davies HT, Crombie IK, Macrae WA, Rogers KM. Pain clinic patients in northern Britain. Pain Clinic. 1992;5(3):129-35.

44. Addington-Hall J, McCarthy M. Dying from cancer: results of a national population-based investigation. Palliat Med. 1995;9(4):295-305.

45. Caraceni A, Portenoy RK. An international survey of cancer pain characteristics and syndromes. IASP Task Force on Cancer Pain. International Association for the Study of Pain. Pain. 1999;82(3):263-74.

46. Bennett MI, Rayment C, Hjermstad M, Aass N, Caraceni A, Kaasa S. Prevalence and aetiology of neuropathic pain in cancer patients: a systematic review. Pain. 2012;153(2):359-65.

47. Roberto A, Deandrea S, Greco MT, Corli O, Negri E, Pizzuto M, Ruggeri F. prevalence of neuropathic pain in cancer patients: pooled estimates from a systematic review of published literature and results from a Survey Conducted in Fifty Italian Palliative Care Centers. J Pain Symptom Manage. 2016;25. pii: S0885-3924(16)30008-2 (Epub ahead of print).

48. Schifitto G, McDermott MP, McArthur JC, Marder K, Sacktor N, Epstein L, et al. Incidence of and risk factors for HIV-associated distal sensory polyneuropathy. Neurology. 2002;58(12):1764-8.

49. Keswani SC, Pardo CA, Cherry CL, Hoke A. McArthur JC. HIV-associated sensory neuropathies. AIDS. 2002;16(16):2105-17.

50. Jenkins PJ, Watts AC, Duckworth AD, McEachan JE. Socioeconomic deprivation and the epidemiology of carpal tunnel syndrome. J Hand Surg Eur. 2012;37(2):123-9.

51. Palmer KT, Harris EC, Coggon D. Carpal tunnel syndrome and its relation to occupation: a systematic literature review. Occup Med (Lond). 2007;57(1):57-66.

52. Sonohata M, Tsuruta T, Mine H, Asami A, Ishii H, Tsunoda K, et al. Clinical characteristics of neuropathic pain in patients with carpal tunnel syndrome. Hand Surg. 2014;19(1):43-8.

53. Orita S, Yamashita T, Ohtori S, Yonenobu K, Kawakami M, Taguchi T, et al. Prevalence and location of neuropathic pain in lumbar spinal disorders: analysis of 1,804 consecutive patients with primary lower back pain. Spine (Phila Pa 1976). 2016;8. [Epub ahead of print].

54. Eide PK. Pathophysiological mechanisms of central neuropathic pain after spinal cord injury. Spinal Cord. 1998;36(9):601-12.

55. Nicholson BD. Evaluation and treatment of central pain syndromes. Neurology. 2004;62(5 Suppl 2):S30-6.

56. Bogousslavsky J, Regli F, Uske A. Thalamic infarcts: clinical syndromes, etiology, and prognosis Neurology. 1988;38(6):837-48

57. MacGowan DJ, Janal MN, Clark WC, Wharton RN, Lazar RM, Sacco RL, et al. Central post stroke pain and Wallenberg's lateral medullary infarction: frequency, character, and determinants in 63 patients. Neurology. 1997;49(1):120-5.

58. Heitmann H, Biberacher V, Tiemann L, Buck D, Loleit V, Selter RC, et al. Prevalence of neuropathic pain in early multiple sclerosis. Mult Scler. 2015;19. pii: 1352458515613643 (Epub ahead of print). 